\title{
ASSESSING NON-NATIVE SPECIES IN THE ANTARTIC MARINE BENTHIC ENVIRONMENT
}

\author{
http://dx.doi.org/10.4322/apa.2014.049 \\ Ana Carolina Fortes Bastos ${ }^{1, *}$, Andrea de Oliveira Ribeiro Junqueira ${ }^{1}$ \\ ${ }^{1}$ Instituto de Biologia, Universidade Federal do Rio de Janeiro - UFRJ \\ *e-mail: carolfbastos@gmail.com
}

Abstract: Bioinvasion is one of the biggest global threats to biodiversity. In the light of climate change, related risks could be increased. In this context, Antarctica is not immune. Exotic species have been introduced into many other isolated ecosystems worldwide and have already been recorded in the sub-Antarctica islands. However, the pool of information concerning the marine environments is too scarce up to the present. This study has investigated the pathways of alien species introduction in the Antarctic marine environment, as a consequence of scientific research, tourism and fishing activities, including the areas of Antarctica vulnerable to bioinvasion. In addition, biogeographic patterns of the some species recorded over the Brazilian program PROANTAR (Phylum Mollusca, Echinodermata, Annelida) have been surveyed. The area of the scientific stations and temporary shelters, which are built in ice-free locations in the summer located mainly in southwestern part of King George Island, close to the Bransfield Strait. The Bellingshausen, President Eduardo Frei Montalva and Arctowski Henryk bases are the oldest in operation. President Eduardo Frei Montalva, King Sejong and Artigas have the largest contingent of people in the summer. Maxwell Bay and Admiralty Bay have the highest number of tourist spots, although King George Bay has the highest tourist landed number. The phylum Artropoda has the greatest biodiversity in the marine environment of Admiralty Bay. The phylum Annelida has the lowest percentage taxa identified to species. Annelida and Artropoda have the highest percentage of endemic species, when only the Antarctic bioregion is considered. On the other hand, Mollusca was the phylum with the highest percentage of species with disjoint distribution.

Keywords: marine-introduction, human activities, pathways, biogeographical components

\section{Introduction}

Bioinvasion is a branch of Science that studies species transportation by human activities, away from their original biogeographic area, in order to comprehend the dispersion patterns, and to identify control measures to mitigate or eliminate possible negative impacts caused by introduced species in a native ecosystem (Villac et al., 2008). These impacts are particularly critical in islands and isolated ecosystems, which have a high degree of endemism and greater vulnerability to invasion by nonnative species (Gaucel et al., 2005).
In the multiple dimensions of global environmental change, the efforts to prevent bioinvasions must be increased. Schiel et al.(2004) state that responses of benthic communities to ocean warming were mostly unpredictable in their research. However, one of the most commonly predicted effects of global ocean warming on marine communities discussed in the literature is a poleward shift in the distributional boundaries of species. Accordingly, it follows that many exotic species can become invasive leading to a decrease in local genetic stock in a process 
referred to as "biotic homogenization" (Vitousek et al. 1997; McKinney \& Lockwood, 1999).

However, assumptions and inferences about the ecology, detection and management of alien species requires a broad range of information about composition and community structure in potential donor and recipient areas of species transfer (Carlton, 2000). Therefore, data such as biogeography, life history and dispersal ability of species studied, as well as human activities that contribute to the spread of these species are becoming essential for any future elaboration of management actions against bioinvasion, especially in environments with large endemism, such as the Antarctic.

All this concern is justified in the Antarctic context. The long period of geographical isolation has culminated in the evolution of specialized endemic species in extreme conditions, although non-native species have been identified in the Antarctic ecosystem, as Poa pratensis and P. annua, detected in small areas in the northeast of the Antarctic Peninsula and King George Island (Smith, 1996). In relation to the Antarctic marine environment, Tavares and De Mello (2004) reported the presence of the exotic crustacean Hyas araneus in Austral Ocean, coming from the North Atlantic. Generally, most of the knowledge about bioinvasion, even for the sub-Antarctic islands, refers to the terrestrial environment (Frenot et al. 2005).

In the light of this scenario, the goals of this study are: I- to search main vectors and pathways of potential introduction to the marine environment, especially in King George Island and to identify the most vulnerable areas; II- to develop a database concerning the pattern of distribution of Mollusca, Annelida, Echinodermata and Artropoda marine species detected in Admiralty Bay by the Brazilian Antarctic Program (Weber \& Montone, 2006).

\section{Material and Methods}

To study the main vectors and pathways of potential introductions in King George Island, three main human activity areas were considered: scientific research in situ, tourism and fishing. According to scientific research the following activities must be considered: field work, experimental design and scientist offset, including the functioning of scientific stations and shelters located on King George Island. On the other hand, it is necessary to fully diagnose the statistical trends concerning the most frequently visited places on this island, both for identifying areas more susceptible to non native species brought by tourism, and for providing the necessary knowledge to improve the management quality of the island. Related data is reviewed on IAATO's site (International Association of Antarctic Tour Operators). The investigations on fishing activities are also contained in the original project, since it is an important sector of non intentional introduction, specially related to marine ecosystems. However, this information was not brought up until now.

To study the species biogeography of the phyla Mollusca, Echinodermata, Annelida and Artropoda (indicated in the project GEAMB- Rede 2), a study was made on their distribution using the online database OBIS - Ocean Biogeography Information System (www.iobis.org) and GBIF - Global Biodiversity Information Facility (www. gbif.org). According to the distribution pattern in marine biogeographic zones proposed by Rass (1986) (Figure 1), species were classified as: I) cosmopolitan: for those of wide distribution and present in at least three ocean basins; II) continuous: for species located in adjacent biogeographic areas (but at a lower rate than required for classification as cosmopolitan), III) disjoint: species that have occurrences in distinct biogeographic regions (separated by areas of nonoccurrence); IV) endemic: for species distributed within the boundaries of the Southern Ocean (biogeographic areas 8 and 9 of Figure 1).

\section{Results}

According to data published by KGIs SCAR (Scientific Committee on Antarctic Research, King George Island) there are ten scientific stations on King George Island: eight permanent (which have activities throughout the year) and two temporary. The permanent stations are: 1) Brazil: Comandante Ferraz, 2) Chile: Presidente Eduardo Frei,

3) Chile: Professor Julio Escudeiro, 4) China: Great Wall,

5) Korea: King Sejong, 6) Poland: Arctowski, 7) Russia: 


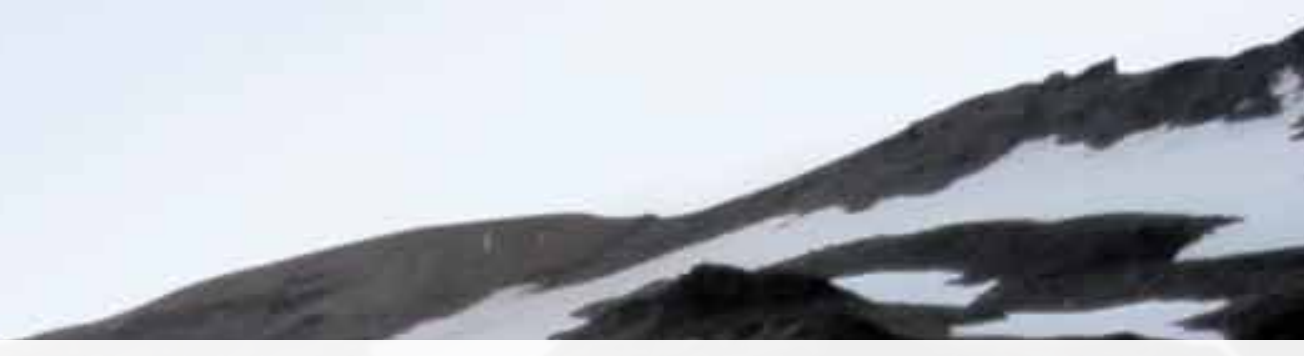

Table 1. Numeric values and percentages of each distribution pattern according to the invertebrate groups.

\begin{tabular}{|c|c|c|c|c|c|c|c|c|}
\hline & \multicolumn{2}{|c|}{ Mollusca } & \multicolumn{2}{|c|}{ Echinodermata } & \multicolumn{2}{|c|}{ Annelida } & \multicolumn{2}{|c|}{ Artropoda } \\
\hline & no & $\%$ & $n \circ$ & $\%$ & $n \circ$ & $\%$ & $n \circ$ & $\%$ \\
\hline No data & 0 & 0 & 0 & 0 & 2 & 5 & 6 & 10 \\
\hline Cosmopolitan & 0 & 0 & 0 & 0 & 5 & 12.5 & 1 & 1.67 \\
\hline Continuous & 11 & 47.83 & 1 & 20 & 3 & 7.5 & 12 & 20 \\
\hline Disjoint & 3 & 13.04 & 0 & 0 & 3 & 7.5 & 2 & 3.33 \\
\hline Endemic & 9 & 39.13 & 4 & 80 & 27 & 67.5 & 39 & 65 \\
\hline Total & 23 & 100 & 5 & 100 & 40 & 100 & 60 & 100 \\
\hline
\end{tabular}

species residents in both Antarctica e subantarctica areas (areas 9 and 8, respectively). When only the Antarctic (area 9) is considered, the phyla Annelida and Artropoda have the highest percentage of endemic species, represented by $25 \%$ for both groups (with 10 and 15 endemic species, respectively). The phylum Mollusca has only one species (4.35\%), while the phylum Echinodermata shows no species restricted to this region.

\section{Discussion}

The scientific stations and temporary shelters are located mainly in southwestern King George Island, closer to the Bransfield Strait. Futhermore, these stations were built in areas where the soil is exposed during the summer, due to the decrease in the percentage of ice cover.

Among the permanent stations, President Eduardo Frei Montalva (Chile), King Sejong (Korea) and Artigas (Uruguay) are the scientific bases that have the largest contingent of people in summer. This means that both the pathways and vectors used by these stations, especially those that have the highest uptime, as well as the largest contingents must be targets of investigation for a possible presence of non-native species, since time and human activities are essential factors in the processes of bioinvasion.

In general, touristic places are related to areas free of ice during the summer, and most of these sites are closer to the Bransfield Strait. Verifying data provided by SCAR KGIs, the Arctowski and Penguin Island stations are the locations of this island where most tourists landed during
1999 to 2002, and, based on tourism activities, these are the places most likely to suffer the unintentional introduction of nonnative species.

Although there is no irrefutable record of invasion in the Antarctic marine environment, more careful studies of species with cosmopolitan or disjoint distribution are necessary, since these patterns can be correlated to taxonomic misidentification and occurrence of cryptic species or, ultimately, to the dispersal of species by human vectors. According to Carlton (2009), the list of invasive species across the planet may be underestimated due to the presence of pseudoindigenous species, here defined as introduced species that are mistakenly considered as native (indigenous or endemic) to a location.

\section{Conclusion}

The results obtained so far do not allow us to make conclusions about the invasive status of species, but provide valuable clues about which species will require more investigation management and monitoring. However, a larger amount of information about vectors and pathways, as well as more vulnerable sites are essential before it is possible to make inferences about the presence of invasive species in the Antarctic marine environment.

\section{Acknowledgements}

We thank the National Institute of Science and Technology Southern Environmental Research (INCT-APA) for financing this work (CNPq process $n^{\circ} 574018 / 2008-5$ and FAPERJ, process no E-16/170.023/2008) 


\section{References
Carlton, J.T. (2000). Global change and biological invasions in the oceans. In: Mooney, H.A.\& Hobbs, R.J. Invasive Species
in a Changing World. Covelo: Island Press. \\ Carlton, J.T. (2009). Deep invasion ecology and the assembly of communities in historical time. In: Rilov, G \& Crooks, J. Biological Invasions in marine ecosystems: Ecological, management and geographic perspectives. Heidelberg: Springer. Ecological Studies 204. \\ Frenot, Y.; Chown, L.S.; Whinam, J.; Selkirk, P.M.; Convey, P.; Skotnicki, M. \& Bergstrom, D.M. 2005. Biological invasions in the Antartic: extent, impacts and implications. Biological Reviews, 80: 45-72. \\ Gaucel, S.; Langlais, M. \& Pontier, D. (2005). Invading introduced species in insular heterogeneous environments. Ecological Modelling, 188: 62-75. \\ McKinney, M.L. \& Lockwood, J.L. (1999). Biotic homogenization: a few winners replacing many losers in the next mass extinction. Trends in Ecology \& Evolution, 14: 450-453.}

Rass, T. S. 1986. Vicariance ichtyogeography of Atlantic Ocean pelagial. Pelagic Biogeography, (49): 237-241.

Schiel, D.R., Steinbeck, J.R \& Foster, M.S. (2004). Ten years of induced ocean warming causes changes in marine benthic communities. Ecology, 85 (7): 1833-1839.

Smith, R.I.L. (1996). Introduced plants in Antarctica: potential impacts and conservation issues. Biological conservation, 76 : 135-146.

Tavares, M. \& De Mello, G.A.S. (2004). Discovery of the first know benthic invasive species in the Southern Ocean: the North America spider Hyas araneus found in the Antarctic Peninsula. Antarctic Science, 16: 129-131.

Villac, M.C.; Ferreira, C.E.L \& Junqueira, A.O.R. (2008). In: Neto, J.A.B.; Wallner-Kersanach, M. \& Patchineelam, S. M. Poluição marinha. Rio de Janeiro: Interciência.

Vitousek, P.M., Mooney, H.A. \& Melillo, J.M. (1997). Human Domination of Earth's Ecosystems. Science, 277: $494-499$.

Weber, R.R \& Montone, R.C. (2006). Rede 2 - Gerenciamento Ambiental na Baía do Almirantado, Ilha Rei George, Antártica. Brasília: Ministério do Meio Ambiente. 259 p. 